\title{
Tuffisitic Kimberlites: Mineralogical Characteristics Relevant to their Formation
}

\author{
Roger H. Mitchell ${ }^{1}$, E. Michael W. Skinner ${ }^{2}$, and Barbara H. Scott Smith \\ ${ }^{1}$ Department of Geology, Lakehead University, Thunder Bay, ON, Canada P7B 5E1 \\ ${ }^{2}$ Department of Geology, Rhodes University, Grahamstown 6140, South Africa \\ ${ }^{3}$ Scott-Smith Petrology Inc., 2555 Edgemont Blvd., North Vancouver, BC, Canada V7R 2M9
}

Tuffisitic kimberlites (TK) are the dominant components of many kimberlite pipes in southern Africa. These rocks are distinct from all other textural varieties of kimberlite. The objective of this study is to investigate the optically intractable features of TK using back-scattered electron (BSE) petrography and quantitative compositional data. The study involves TKs from the Wesselton Mine, a type area pipe in Kimberley, South Africa. Wesselton was selected because: it has been mined since 1890, it is a type locality for fresh archetypal holocrystalline coherent kimberlite (13-33 modal \% olivine macrocrysts, 16-26 modal \% olivine phenocrysts, 4 - 16 modal \% monticellite, up to 13 modal \% groundmass phlogopite, up to 16 modal \% carbonate, serpentine, spinel, perovskite, apatite, but no clinopyroxene; and detailed investigations have shown that the pipe includes at least ten phases of kimberlite ranging from typical hypabyssal kimberlite (HK) to volumetrically significant TK to depths of $>930 \mathrm{~m}$ as well as HK to TK transitional textures (Fig. 1; Clement 1982, Shee 1985).

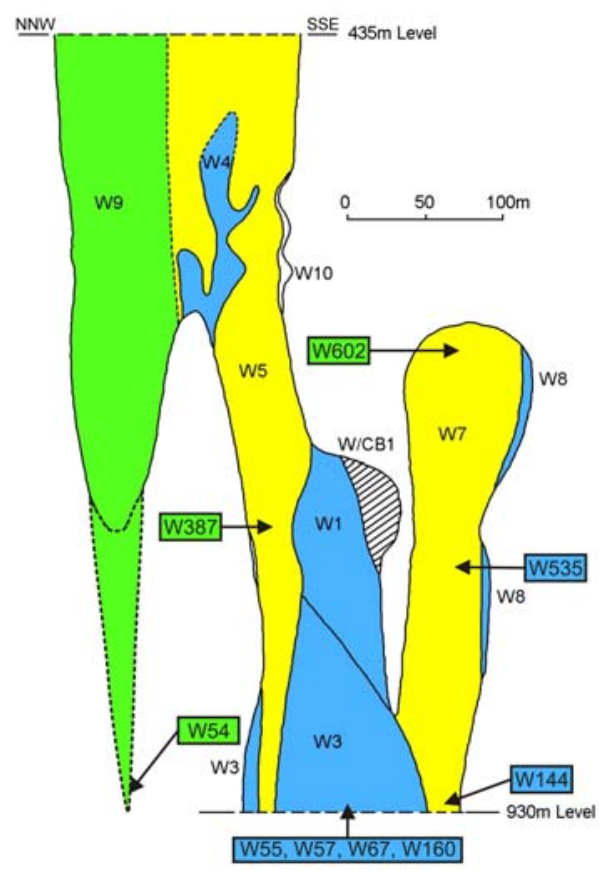

Fig. 1 Vertical cross section through the Wesselton pipe showing the dominant textural mode of some phases of kimberlite (after Clement 1982; W1, W3,
W4, W5, W7, W8, W9 and W10 are separate phases of kimberlite; W/CB1 is a country rock breccia; solid lines are sharp internal contacts; green = TK; blue = $\mathrm{HK}$, yellow = transitional between $\mathrm{HK}$ and $\mathrm{TK}$; (mining levels are depths below the present surface). Also shown are the location of the three representative TK samples investigated in this study (samples W54, W387, W602), and some samples of type HK (W55, W57, W67, W144, W160, W535 from Shee 1985). The W9 phase extends to at least the $930 \mathrm{~m}$ level outside the plane of this cross section (projected here as dotted lines from in data in Fig. 3.29 of Clement 1982).

The Wesselton samples exhibit all the hallmark/characteristic features of TK (Fig. 2). They are generally massive, unsorted, matrix- to clastsupported rocks which contain the following components in variable modal quantities: abundant anhedral pseudomorphed olivine macrocrysts and euhedral phenocrysts; lesser abundances of other mantle-derived macrocrysts (e.g. garnet, ilmenite); a specific assemblage of magmaclasts (formerly pelletal lapilli; Fig. 3); thin cryptocrystalline mantles on the preceeding constituents (Fig.4, 5); and an interclast matrix (Fig. 5, 6). Xenoliths derived from the local country rock are common. The character of the magmaclasts, mantles and interclast material in the three phases of TK are similar and all carbonate-poor. The size and distribution of the olivines is similar to that of hypabyssal kimberlite. Broken olivines are not observed. The olivine grains, whether enclosed in a magmaclast or not, are completely pseudomorphed by chlorite and mixed layer smectite-chlorite (Figs. 2 - 4). Clastic matrices and/or accretionary clasts are not present. The morphology of the magmaclasts ranges from sub-spherical to elliptical, less commonly to curviplanar, many of which are $<10 \mathrm{~mm}$ in size. They are typically (Fig. 3) composed of several crystals of olivine set in a microcrystalline groundmass of diopside, apatite, fresh and/or chloritised phlogopite, perovskite and spinel and very rarely calcite). They may, or may not, have a kernel of an inherited solid, i.e. olivine grain or xenolith. Most of the components described above are surrounded by thin mantles dominated by diopside and phlogopite microlites (Figs.4, 5). The interclast matrix consists principally of microlitic chlorite and mixed layer smectite-chlorite (saponite) after phlogopite and lesser diopside (Fig. 6). The boundaries of the magmaclasts are commonly relatively well defined whereas those of the mantle to interclast matrices are typically diffuse. Most of the 
fine grained minerals are primary because they occur with contrasting habits within the magmaclast, mantle and interclast matrix; there are no replacement textures. Diopside within the magmaclast groundmass occurs as subhedral equant grains intimately intergrown with phlogopite and apatite. Diopside in the mantles occurs as microlitic, acicular discrete crystals which protrude into the interclast matrix. The latter consists of similar microlitic diopside set in a felt-like aggregate of smectite/chlorite (saponite) plates. Xenoliths occur with and without microlitic mantles.

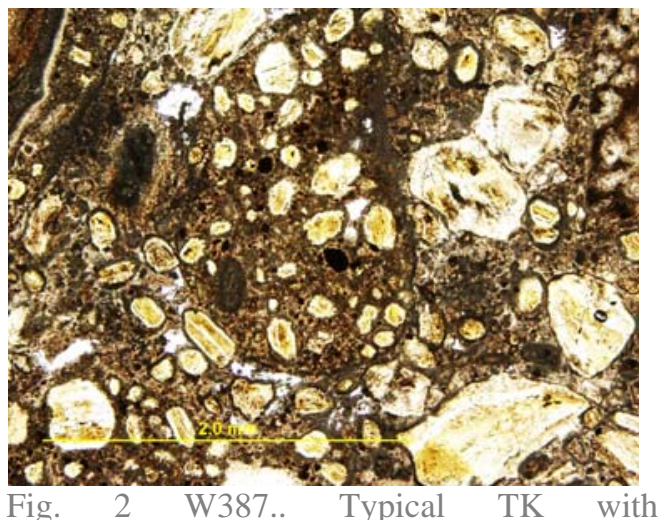

magmaclasts containing pseudomorphed olivine set in fine grained interclast matrix. Plane polarised light image.

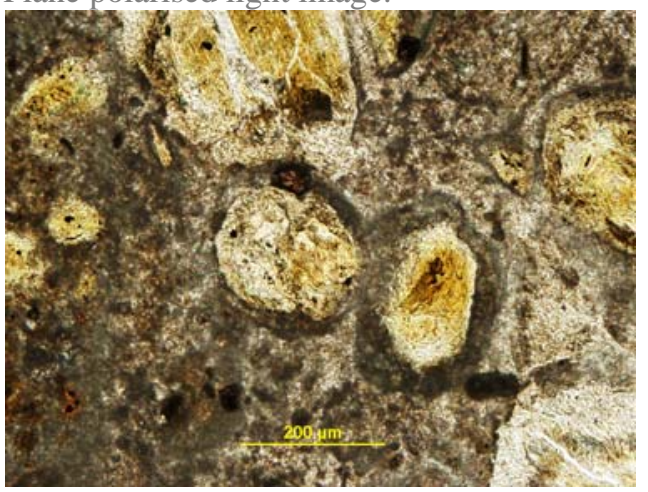

Fig. 3 W387. Diopside+phlogopite mantles on chlorite pseudomorphed olivine. Plane polarised light image.

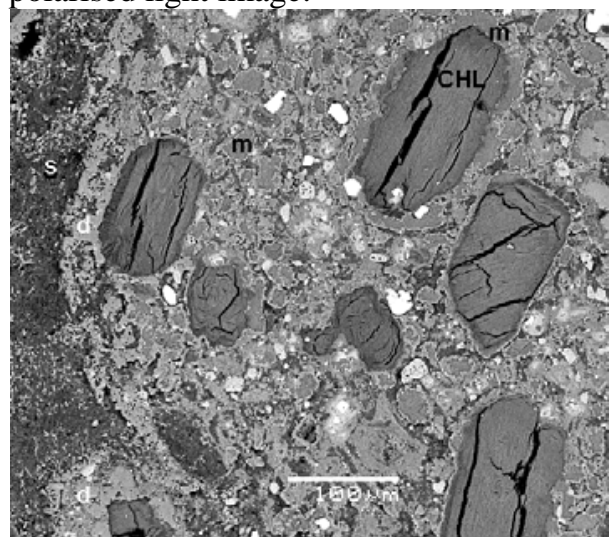

Fig. 4. W387. Magmaclast with chlorite pseudomorphed olivine (CHL), diopside microlites (d), fresh mica (m), and smectitechlorite (saponite) interclast matrix. BSEimage.

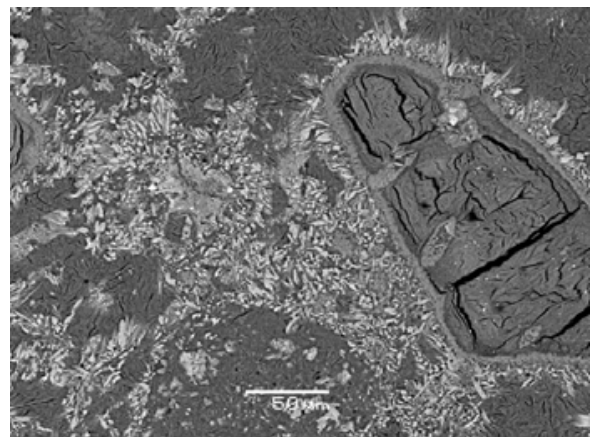

Fig. 5 W387. Fringing microlitic diopside and phlogopite with smectite-chlorite-diopside interclast matrix. BSE-image.

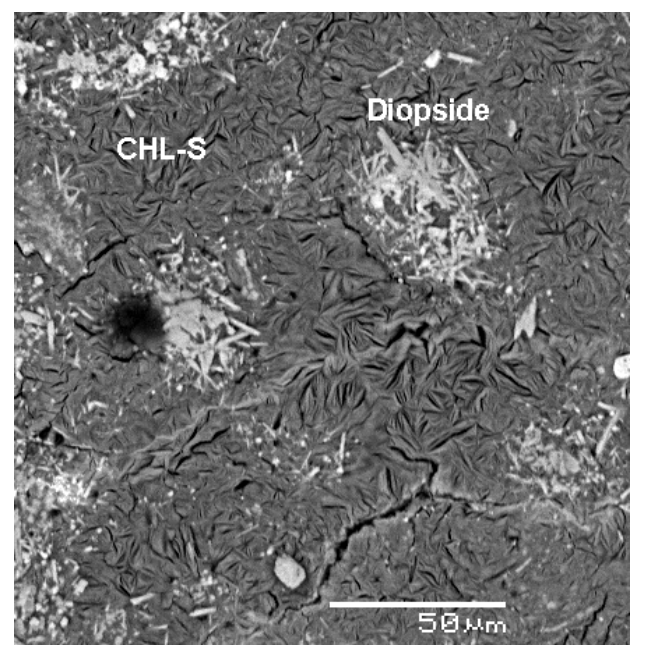

Fig. 6 W602. Smectite-chlorite interclast matrix. BSE-image.

Diopsides (2-8 wt.\% FeO) in the magmaclasts, mantles and the interclast matrix are all poor in $\mathrm{Al}_{2} \mathrm{O}_{3}, \mathrm{Cr}_{2} \mathrm{O}_{3}$, $\mathrm{TiO}_{2}$, and $\mathrm{Na}_{2} \mathrm{O} \quad(<1$ wt.\%). Phlogopite in the magmaclasts contains $<0.5$ wt.\% $\mathrm{Cr}_{2} \mathrm{O}_{3}$, up to 4 wt. \% $\mathrm{TiO}_{2}$ and up to $8 \mathrm{wt}$.\% FeO. The spinels, in terms of their $\mathrm{TiO}_{2}, \mathrm{Cr}_{2} \mathrm{O}_{3}$ and $\mathrm{MgO}$ contents, are unevolved titaniferous magnesian chromites and similar to the least evolved spinels in Wesselton HK (Fig. 7).

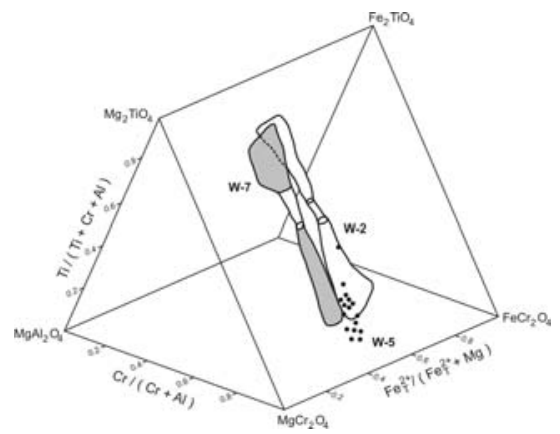

Fig.7 . Composition of spinels in W5 (TK) and W2/W7 (HK; Shee 1985)

Chlorites replacing all olivine in magmaclasts and macrocrysts are Fe-rich aluminous clinochlore (6-8 wt.\% $\mathrm{Al}_{2} \mathrm{O}_{3} ; 8-14$ wt.\% $\mathrm{FeO}_{\mathrm{T}}$ ). These chlorites are replaced at their margins by $\mathrm{Fe}$-poor smectite-chlorite- 
(saponite) similar to that occurring in the groundmass of the magmaclasts and the interclast matrix. The latter consists of Fe-poor (1-4 wt.\% $\mathrm{FeO}_{\mathrm{T}}$ ), Na-bearing (2-3 wt.\% $\mathrm{Na}_{2} \mathrm{O}$ ) smectite-chlorite (saponite). The olivine pseudomorphs are composed of chlorite resulting from one or more phases of deuteric replacement that occurred before, and under different conditions to, the formation of the chlorites in the magmaclasts and interclast matrix. There is no relict serpentine in the pseudomorphs. The differences in chlorite-saponite composition between pseudomorphs and interclast matrix shows that the chlorite-saponite cannot result from pervasive secondary post consolidation replacement. This suggests the samples are fresh, (consistent with their derivation from a deep location which has not been subjected to subaerial weathering), and have only undergone several types of deuteric replacement processes. Mixed layer smectite-chlorite (saponite) is considered to have formed from a phlogopite precursor.

Some magmaclasts in sample W54 (phase W9) contain a blocky prismatic phase (? monticellite) that has apparently been pseudomorphed initially by phlogopite and subsequently by K-bearing celadonite-smectite.

The granularity and mineralogy of the magmaclasts is comparable in some respects to that of HK (e.g. distribution of olivines, the presence of primary phlogopite, apatite, perovskite, spinel, minor primary calcite); this shows that the larger magmaclasts formed from normal kimberlite magma. Differences from HK include the finer groundmass grain sizes, the absence of highly evolved spinel compositions, the presence of clinopyroxene and the lack of textural or compositional evidence for the presence of groundmass monticellite. Clinopyroxene is a primary phase crystallizing instead of monticellite, possibly as a result of the loss of $\mathrm{CO}_{2}$ as reflected in the paucity of carbonate relative to most HKs. The finer grain sizes and lack of spinel evolution suggest that the usual crystallization sequence of HK was arrested prematurely. The formation of the magmaclasts occurred before the crystallization of the mantle and interclast matrix. The mineralogical relationships and boundaries between the mantles and interclast matrix indicate a continuum of variable crystallization within an evolving magmatic system consisting of fluids plus magmaclasts rather than a coherent magma. The mantles result from the decoration of the magmaclasts by fringing microlites. The final stages of the crystallization continuum are represented by smectite-chlorite with textures suggestive of pseudomorphed phlogopite, together with lesser diopside in the interclast matrix, where there is no textural or compositional evidence for the presence of serpentine. The occurrence of microlitic primary minerals in the mantle and interclast matrix reflects crystallization conditions changing from magmatic to late-stage vapour-phase crystallization of residual fluids between non-welded magmaclasts. In turn, this shows that the magma remaining after the formation of the magmaclasts is a $\mathrm{CO}_{2}$-poor, $\mathrm{H}_{2} \mathrm{O}-, \mathrm{K}_{2} \mathrm{O}-, \mathrm{CaO}$-,
$\mathrm{MgO}$-rich and $\mathrm{SiO}_{2}$-bearing fluid. These features show that the interclast matrix is neither a secondary replacement nor a cement introduced from external sources. The magmaclasts are remnants of the original magma dispersed through a fluid host from which the microlites crystallizes as a rock forming mineral.

Features similar to those described above occur in TK from Kao (K6), Letseng, Ebenhaezer, Premier, and Venetia. These textural and paragenetic characteristics are unique to this variety of kimberlite. These features suggest that each TK forms by the textural and mineralogical modification of the magma under rapidly changing conditions resulting from volatile exsolutioninduced segregation and progressive crystallization of a single subsurface kimberlite magmatic system. The constituents formed within the diatreme without ejection from the vent and are thus subvolcanic. These conclusions based on the examination of TKs are consistent with the textural transitions from TK to HK in the root zone within single phases of kimberlite (Clement 1982, Skinner and Marsh 2004). The widespread microlitic textures show repeated en masse crystallization in each TK within diatremes resulting from a very rapid drop in temperature.

The magmaclasts in TKs are distinct from the subaerial, juvenile melt-bearing pyroclasts of the type first recognised in kimberlites from Saskatchewan, Canada (Scott Smith 2008). The latter are commonly amoeboid to sub-spherical in shape with well-defined, smooth fluidal outlines, and rapidly cooled-toquenched groundmasses which are in parts vesicular. They are formed by the fragmentation of kimberlite magma during standard styles of pyroclastic eruption and ejection from a vent (juvenile lapilli and ash) commonly with sorting prior to deposition. We consider on the basis of significant mineralogical and petrographic differences between these pyroclasts and TK-magmaclasts that TKs cannot represent fall-back pyroclastic material.

\section{References}

Clement, C.R. 1982. A comparative geological study of some major kimberlite pipes in the northern Cape and Orange Free State. Unpublished Ph.D. thesis, University of Cape Town, South Africa.

Scott Smith B.H. 2008 The Fort á la Corne kimberlites, Saskatchewan,Canada: geology, emplacement and economics. Journal of the Geological Society of India, 71, p. 1-55.

Shee S.R. 1985. The petrogenesis of the Wesselton Mine, Kimberley, Cape Province, RSA. Unpublished Ph.D. Thesis, University of Cape Town, South Africa.

Skinner, E.M.W., Marsh, J.S., 2004. Distinct kimberlite pipe classes with contrasting eruption processes. Lithos 76, 183-200. 